\title{
Regulation of De Novo Purine Synthesis in Human Bone Marrow Mononuclear Cells by Hypoxanthine
}

\author{
Mark E. King, J. Michael Honeysett, and Stephen B. Howell, Department of \\ Medicine, the Cancer Center, University of California, San Diego, \\ La Jolla, California 92093
}

\begin{abstract}
A B S T R A C T In previous studies from this laboratory, human bone marrow hypoxanthine concentrations were found to average $7.1 \mu \mathrm{M}$, three times higher than plasma hypoxanthine concentrations measured simultaneously. To assess the significance of this finding, the relationship between hypoxanthine concentration and the rate of purine nucleotide synthesis by the de novo pathway was studied in normal human bone marrow mononuclear cells and in the human promyelocytic cell line, HL-60, in vitro. Utilizing a $\left[{ }^{14} \mathrm{C}\right]$ formate incorporation technique, rates of total cellular de novo purine synthesis as well as rates of de novo adenine, de novo guanine, and thymine synthesis and incorporation into RNA and DNA were measured as a function of hypoxanthine concentration. In normal human marrow cells, the rate of total de novo purine synthesis declined by $81 \%$, while the rate of de novo adenine and de novo guanine synthesis and incorporation into macromolecules declined by 89 and $75 \%$, respectively, when media hypoxanthine was increased from 0 to 10 $\mu \mathrm{M}$. Similar results were seen in the HL-60 cell line. In contrast, rates of thymine synthesis and incorporation into DNA as well as overall rates of RNA and DNA synthesis did not change with varying media hypoxanthine concentrations. In addition, hypoxanthine salvage and incorporation into RNA and DNA was shown to progressively increase with increasing media hypoxanthine concentrations. These results indicate that physiologic concentrations of hypoxanthine are sufficient to regulate the rate of de novo purine synthesis in human bone marrow in vivo.
\end{abstract}

\section{INTRODUCTION}

Purine nucleotides participate in a wide variety of cellular functions. They serve as the building blocks

Dr. Howell is a Clayton Foundation investigator. Dr. King's present address is Oklahoma City Clinic, Oklahoma City, OK 73104.

Received for publication 1 November 1982 and in revised form 6 May 1983 . of RNA and DNA, they regulate enzymatic activity as components of vitamins and cofactors, and they mediate energy transfer in the cell. This remarkable diversity of function emphasizes the fundamental importance of these compounds. Mammalian cells obtain purine nucleotides through two separate metabolic pathways: by de novo synthesis utilizing 5 -phosphoribosyl-1-pyrophosphate (PRPP) ${ }^{1}$ and glutamine or by salvage of extracellular purine bases and nucleosides. The regulation of these pathways has been the subject of numerous investigations, and an early observation was the strikingly low rate of de novo purine synthesis in several normal tissues, including intestine and bone marrow (1-5). It has been suggested that these tissues have little, if any, capacity for de novo purine synthesis and are therefore dependent on the salvage of circulating purines $(5,6)$. Recent studies in this laboratory have demonstrated a much higher concentration of the purine base hypoxanthine in human bone marrow than in plasma (7). This observation has been confirmed by other investigators (8). The average hypoxanthine concentration in eight bone marrow samples was $7.1 \mu \mathrm{M}$ (range 1.9 to $20 \mu \mathrm{M}$ ), while that in venous plasma measured simultaneously was $2.0 \mu \mathrm{M}$ (range 0.8 to 7.9 $\mu \mathrm{M})$. Hypoxanthine has been shown to inhibit the de novo pathway of purine biosynthesis in human and animal cells in vitro (9-15). Therefore, the apparent absence of de novo purine synthesis in bone marrow may have been the result of inhibition of this pathway by elevated concentrations of hypoxanthine.

In the present study, the effect of varying media concentrations of hypoxanthine on the rate of de novo purine synthesis was investigated in normal human bone marrow mononuclear cells and in the human promyelocytic leukemia cell line, HL-60, in vitro. The results demonstrate that physiologic levels of hypo-

\footnotetext{
${ }^{1}$ Abbreviations used in this paper: PRPP, 5-phosphoribosyl-1-pyrophosphate.
} 
xanthine markedly reduce the rate of de novo purine synthesis in both human marrow and HL-60 cells. This finding indicates a key regulatory role for physiologic concentrations of hypoxanthine in purine nucleotide metabolism.

\section{METHODS}

HL-60 cell line and bone marrow samples. The human promyelocytic cell line HL-60 (16) was obtained from Dr. Steven Collins (Veterans Administration Medical Center, Seattle, WA). Exponentially growing cells were routinely cultured in RPMI 1640 medium (cell culture facility, University of California, San Diego, La Jolla, CA) supplemented with $10 \%$ fetal calf serum (Irvine Scientific, Santa Ana, CA), $1 \%$ glutamine, and $1 \%$ antibiotic/antimycotic mixture (both from Gibco Laboratories, Grand Island, NY). Before use in the experiments described below, cells were washed and resuspended in RPMI 1640 alone to eliminate preformed purines from the media.

Heparinized bone marrow aspirates were obtained from either normal volunteers or patients undergoing staging bone marrow examinations in the evaluation of cancer. In all cancer patients reported here, concomitant histologic studies of bone marrow aspirate and biopsy material were normal. The bone marrow mononuclear cells were isolated by Ficoll-Hypaque gradient centrifugation (17) and resuspended in RPMI 1640 medium. The viability of both cultured and bone marrow cells during the incubation periods of experiments described below was $>95 \%$ by trypan blue dye exclusion.

Measurement of rates of total cellular de novo purine synthesis. Rates of total cellular de novo purine synthesis were determined by a modification of the method of Hershfield and Seegmiller (12). $2-\mathrm{ml}$ samples of cells $\left(10^{6}\right.$ cells $\left./ \mathrm{ml}\right)$ were incubated in concentrations of hypoxanthine (Sigma Chemical Co., St. Louis, MO) varying 0-10 mmol for $60 \mathrm{~min}$ at $37^{\circ} \mathrm{C}$ under a $5 \% \mathrm{CO}_{2}$ atmosphere with occasional shaking. Then $10 \mu \mathrm{l}$ of $\left[{ }^{14} \mathrm{C}\right]$ formic acid $(1 \mathrm{mCi} / \mathrm{ml}, 60.7 \mathrm{mCi} / \mathrm{mmol}$; Research Products International Corp., Mount Prospect, IL) was added to each sample and the incubation continued for another $90 \mathrm{~min}$. The incubation was terminated by centrifugation at $4^{\circ} \mathrm{C}$ for $4 \mathrm{~min}$ at $500 \mathrm{~g}$. The cell pellet was resuspended in $2 \mathrm{ml}$ of $0.4 \mathrm{~N}$ perchloric acid. The sample was then boiled in a water bath for $60 \mathrm{~min}$ and centrifuged for $10 \mathrm{~min}$ at $1,500 \mathrm{~g}$. The supernatant (containing the free purine bases derived from both the acid-soluble and -insoluble purine pools) was applied to a $2.0 \times 0.4-\mathrm{cm}$ column of Dowex 50W-X4 cation exchange resin (Bio-Rad Laboratories, Richmond, CA) and washed with $15 \mathrm{ml}$ of $0.1 \mathrm{~N} \mathrm{HCl}$. The purine bases were eluted with $5 \mathrm{ml}$ of $5 \mathrm{~N} \mathrm{HCl} .1 \mathrm{ml}$ of the eluate was added to $10 \mathrm{ml}$ of Aquasol (New England Nuclear, Boston, MA) and quantitated by liquid scintillation counting.

Measurement of rates of de novo adenine, de novo guanine, and thymine synthesis and incorporation into DNA and RNA. In separate experiments, rates of $\left[{ }^{14} \mathrm{C}\right]$ formate incorporation into the adenine, guanine, and thymine bases of newly synthesized RNA and DNA were measured. Cells were first incubated in varying concentrations of hypoxanthine and subsequently in $\left[{ }^{14} \mathrm{C}\right]$ formic acid with termination of the incubation by centrifugation as described above. The cell pellet was resuspended in $2 \mathrm{ml}$ of ice-cold $10 \%$ trichloroacetic acid and maintained on ice for $10 \mathrm{~min}$. Samples were then centrifuged at $4^{\circ} \mathrm{C}$ for $10 \mathrm{~min}$ at $1,500 \mathrm{~g}$ and the supernatents discarded. The pellet was resuspended in 100 $\mu \mathrm{l}$ of $10 \mathrm{~N}$ perchloric acid and boiled in a water bath for 60 min. After cooling, the samples were diluted with $400 \mu$ l of water and neutralized with $6 \mathrm{ml}$ of alanine/freon as described by Khym (18). A 150- $\mu$ l aliquot of each resulting sample was then subjected to high pressure liquid chromatographic analysis of purine and pyrimidine base content using a method similar to that of Willis et al. (19). Chromatography was performed using a Waters Associates liquid chromatograph at ambient temperature on a Bondapak C18 reverse phase column (Waters Associates, Inc., Milford, MA) with a gradient developed from buffer A (10 mM potassium phosphate, pH 5.0) and buffer B (60\% methanol in water). Absorbance was measured at $254 \mathrm{nM}$ and $280 \mathrm{nM}$ and peak areas determined with a Waters Associates model 730 data module. The bases were quantitated and elution times confirmed by comparison with pure standards. The adenine, guanine, and thymine peaks were collected separately and quantitated in $10-\mathrm{ml}$ volumes of Aquasol by liquid scintillation counting.

Measurement of rates of purine salvage incorporation into RNA and DNA. In the HL-60 cell line, rates of hypoxanthine salvage and incorporation into RNA and DNA were determined with varying media hypoxanthine concentrations. $2-\mathrm{ml}$ aliquots of cells $\left(10^{6}\right.$ cells $\left./ \mathrm{ml}\right)$ were incubated for $90 \mathrm{~min}$ in $\left[{ }^{14} \mathrm{C}\right]$ hy poxanthine $(0.1 \mathrm{mCi} / \mathrm{ml}, 56 \mathrm{mCi} / \mathrm{mmol}$; Moravek Biochemical, City of Industry, CA). The total media hypoxanthine concentration varied from 0.1 to $10 \mu \mathrm{M}$, but serial dilutions of stock $\left[{ }^{14} \mathrm{C}\right]$ hypoxanthine were used such that the specific activity of the $\left[{ }^{14} \mathrm{C}\right]$ hypoxanthine was the same $(56 \mathrm{mCi} / \mathrm{mmol})$ for each sample. The incubation was terminated by centrifugation at $4^{\circ} \mathrm{C}$ for $5 \mathrm{~min}$ at $500 \mathrm{~g}$ and the supernatent discarded. The cell pellet was resuspended in $2 \mathrm{ml}$ of ice-cold $10 \%$ trichloroacetic acid and maintained on ice for $20 \mathrm{~min}$. The precipitate was collected on $\mathrm{GF} / \mathrm{C}$ filter paper (Whatman Chemical Separation Inc., Clifton, $\mathrm{NJ}$ ) and washed three times with $5 \mathrm{ml}$ of cold $10 \%$ trichloroacetic acid. The filters were dried and then suspended in $10 \mathrm{ml}$ of Betaphase (West Chem Products, San Diego, CA) and quantitated by liquid scintillation counting.

Measurement of rates of RNA and DNA synthesis. In the HL-60 cell line, rates of RNA and DNA synthesis were determined with varying media hypoxanthine concentrations. $2-\mathrm{ml}$ aliquots of cells $\left(10^{6}\right.$ cells $\left./ \mathrm{ml}\right)$ were incubated in concentrations of hypoxanthine ranging from 0.1 to $10 \mu \mathrm{M}$ for $60 \mathrm{~min}$ with occasional shaking. Then $1 \mu \mathrm{Ci}$ of $\left[{ }^{3} \mathrm{H}\right]$ uridine $(1.0 \mathrm{mCi} / \mathrm{ml}, 23.4 \mathrm{Ci} / \mathrm{mmol}$; New England Nuclear) or 1 $\mu \mathrm{Ci}$ of $\left[{ }^{3} \mathrm{H}\right]$ thymidine $(1.0 \mathrm{mCi} / \mathrm{ml}, 21.5 \mathrm{Ci} / \mathrm{mmol} ; \mathrm{New}$ England Nuclear) was added and the incubation continued for $30 \mathrm{~min}$. The incubation was terminated by centrifugation at $4^{\circ} \mathrm{C}$ for $5 \mathrm{~min}$ at $500 \mathrm{~g}$ and the supernatent discarded. The cell pellet was resuspended in $2 \mathrm{ml}$ of ice-cold $10 \%$ trichloroacetic acid and maintained on ice for $20 \mathrm{~min}$. The precipitate was collected on Whatman GF/C filter paper, washed, and quantitated by liquid scintillation counting as described above.

\section{RESULTS}

Using a $\left[{ }^{14} \mathrm{C}\right]$ formate labeling technique, rates of total cellular de novo purine synthesis were measured in normal human bone marrow and HL-60 cells in the presence of varying media hypoxanthine concentrations. Combined results for three experiments using human marrow with duplicate or triplicate samples are shown in Fig. 1. As the concentration of hypoxanthine was increased from 0.1 to $10 \mu \mathrm{M}$, total cellular 


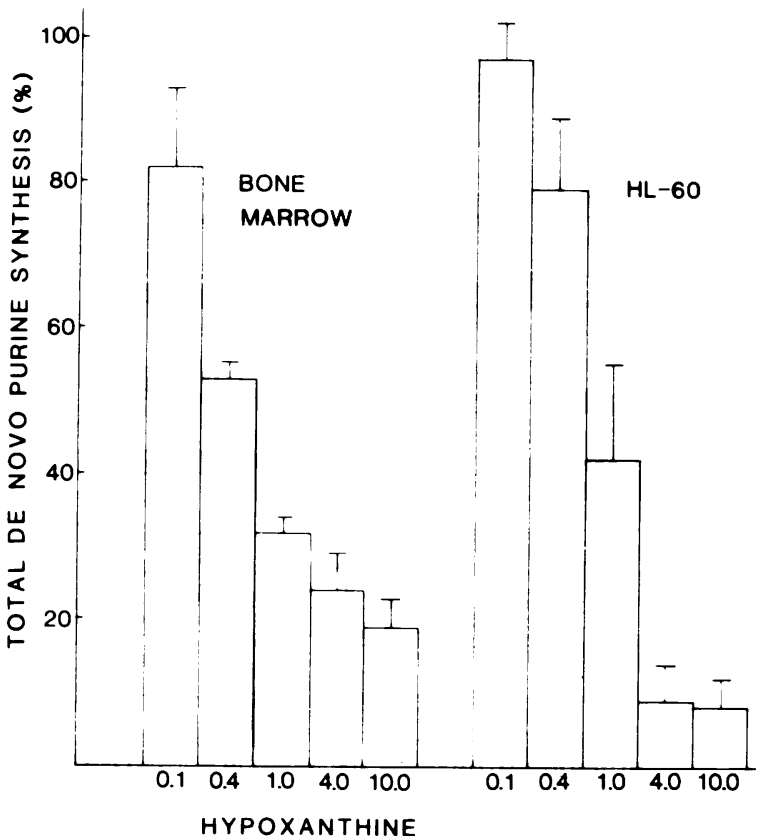

Figure 1 Effect of media hypoxanthine concentration (micromolar) on rates of total cellular de novo purine synthesis. Human bone marrow mononuclear cells or HL-60 human promyelocytic leukemia cells were preincubated in varying concentrations of hypoxanthine for $60 \mathrm{~min}$ and subsequently exposed to $\left[{ }^{14} \mathrm{C}\right]$ formate for $90 \mathrm{~min}$. Total $\left[{ }^{14} \mathrm{C}\right]$ formate uptake and incorporation was then determined. Results are expressed as a percentage of controls, i.e., $\left[{ }^{14} \mathrm{C}\right]$ formate uptake and incorporation found when no hypoxanthine was added to preincubation media. Control values averaged $742 \mathrm{cpm} /$ point for human bone marrow and $4,143 \mathrm{cpm} /$ point for HL-60.

de novo purine synthesis progressively declined from 82 to $19 \%$ of that seen when no hypoxanthine was added to the media. Combined results for three experiments with triplicate samples utilizing the HL-60 cell line are also shown in Fig. 1, and are similar to those for human marrow. The $\mathrm{ID}_{50}$ concentrations of hypoxanthine estimated from these data are 0.4 and $0.8 \mu \mathrm{M}$ for human marrow and HL-60, respectively. These hypoxanthine concentrations are well below those found in human bone marrow in vivo (7).

In other experiments, the effect of media hypoxanthine concentration on the amount of adenine, guanine, and thymine synthesized and subsequently incorporated in RNA and DNA macromolecules was examined. For each concentration of hypoxanthine, these bases were isolated from DNA and RNA and quantified using a chromatographic technique. $\left[{ }^{14} \mathrm{C}\right]$ Formate incorporation into each base was measured by liquid scintillation counting, and the specific activity determined. Results are expressed as a percentage of the specific activity found when no hypo- xanthine was added to the media and are shown in Fig. 2. These results represent three experiments in duplicate or triplicate for human bone marrow and two experiments in triplicate for HL-60. As the media concentration of hypoxanthine was increased from 0 to $10 \mu \mathrm{M}$, the amount of adenine and guanine derived from the de novo synthesis pathway progressively declined by 89 and $75 \%$, respectively, in human marrow mononuclear cells (Fig. 2). Under the same conditions, the specific activity of the thymine peak remained relatively constant; and thus the ratio of de novo purine to thymine synthesis and incorporation rates also progressively declined as a function of media hypoxanthine. Similar results were found in the HL-60 cell line, as shown in Fig. 2.

Synthesis of RNA and DNA requires adequate pools of both purine and pyrimidine nucleotides. The reduction in total de novo purine synthesis and the decline in the ratio of the rates of de novo purine to thymine synthesis demonstrated above suggests that, as media hypoxanthine concentration increases, cellular utilization of the purine salvage pathway correspondingly increases. This suggestion was investigated in the HL-60 cell line, and results are shown in Fig. 3, which represents two experiments with duplicate samples. A 10-fold increase in the rate of hypoxanthine incorporation into RNA and DNA was noted as media hypoxanthine concentration increased from 0.1 to $10 \mu \mathrm{M}$. Near maximal rates of hypoxanthine incorporation were seen with media hypoxanthine concentrations of $4.0 \mu \mathrm{M}$, a concentration well within that range seen in human bone marrow in vivo (7).

Because the reductions in de novo purine synthesis rates demonstrated above might in part be explained by attenuation of cellular RNA and DNA synthesis, rates of RNA and DNA synthesis were examined as a function of media hypoxanthine concentration in the HL-60 cell line. Results are shown in Table I. These data demonstrate that in HL-60 cells, media hypoxanthine concentrations from 0 to $10 \mu \mathrm{M}$ had no significant effect on rates of $\left[{ }^{3} \mathrm{H}\right]$ uridine and $\left[{ }^{3} \mathrm{H}\right]$ thymidine incorporation into RNA and DNA, respectively. This suggests that rates of RNA and DNA synthesis remained constant over this range of media, hypoxanthine concentrations. However, it is possible that with increasing hypoxanthine concentrations, PRPP levels and the uridine monophosphate pool may have been progressively depleted, resulting in relatively stable rates of $\left[{ }^{3} \mathrm{H}\right]$ uridine incorporation into RNA despite a decline in the rate of RNA synthesis. Over the same range of hypoxanthine concentrations, thymine synthesis and incorporation into macromolecules was also relatively stable in human marrow mononuclear cells (Fig. 2), suggesting that rates of DNA synthesis in these cells were similarly unaffected. 

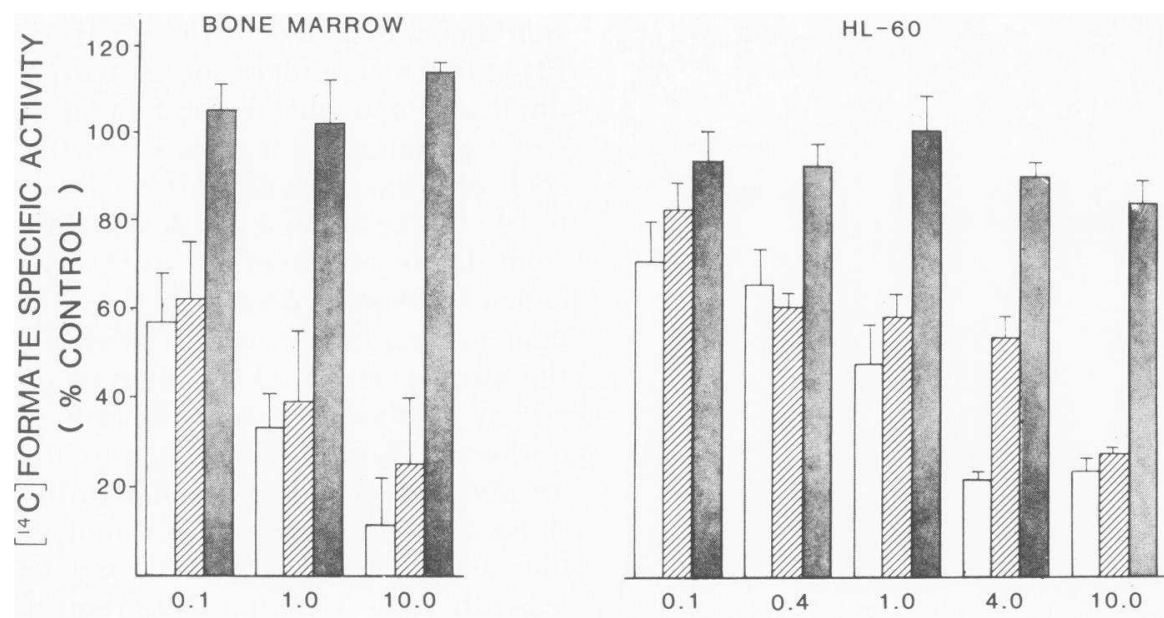

HYPOXANTHINE

Figure 2 Effect of media hypoxanthine concentration (micromolar) on rates of de novo adenine (light bars), de novo guanine (striped bars), and thymine (dark bars) synthesis. Cells were preincubated in hypoxanthine and subsequently exposed to $\left[{ }^{14} \mathrm{C}\right]$ formate as described in Fig. 1. Purine and thymine bases were then isolated from cellular RNA and DNA and quantified chromatographically. $\left[{ }^{14} \mathrm{C}\right]$ Formate incorporation into each base was measured by liquid scintillation and specific activity was determined. Results are expressed as a percentage of controls, i.e., the specific activity found when no hypoxanthine was added to the preincubation media. Control values for human bone marrow averaged 409 (adenine), 477 (guanine), and 1,380 (thymine) cpm/10 nmol base isolated. For HL-60, control values averaged 320 (adenine), 799 (guanine), and 1,092 (thymine) $\mathrm{cpm} / 10 \mathrm{nmol}$ base isolated.

\section{DISCUSSION}

Despite extensive investigation of the pathways of cellular purine metabolism, the precise controls governing purine synthesis, release, and degradation in mammalian tissues remain poorly understood. In early studies by Abrams and Goldfinger (1), Trotter (3), and Lajtha and Vane (6), rates of de novo purine synthesis were found to be very low in bone marrow tissues despite high rates of purine turnover, suggesting that these cells were dependent upon the salvage of circulating purines. This view continues to be accepted by many authors today $(20,21)$, but the details of such a system of purine salvage and reutilization have not been fully elucidated. Recently, high levels of hypoxanthine have been found in human bone marrow (7, 8 ), and in the present study the role of hypoxanthine in bone marrow purine metabolism was investigated. Our results demonstrate that physiologic concentrations of hypoxanthine inhibit de novo purine synthesis in both normal human bone marrow mononuclear cells and in a related cell line, HL-60. In HL-60 cells, hypoxanthine was shown to be preferentially utilized for purine nucleotide synthesis by the salvage pathway. Rates of RNA and DNA synthesis appeared to remain constant over a wide range of hypoxanthine concentrations, demonstrating the capacity for rapid adjust- ment in the balance between purine de novo synthesis and salvage in these cells. These results suggest a key regulatory role for hypoxanthine in purine metabolism and explain the low rates of de novo purine synthesis previously observed in bone marrow tissues. They are supported by similar observations of hypoxanthine inhibition of de novo purine synthesis in cultured human solid tumor cells (10), in freshly harvested human acute leukemia cells (9), and in a human lymphoblastic cell line $(12,13)$. The proposed mechanisms of this effect include $(a)$ nucleotide feedback inhibition of PRPP amido-transferase at the rate-limiting step of $d e$ novo purine synthesis $(15,20) ;(b)$ competition for PRPP, which is required for both hypoxanthine salvage in the phosphoribosyltransferase reaction and for de novo purine synthesis at the PRPP amido-transferase step (20); and (c) nucleotide feedback inhibition of PRPP synthetase, the first enzyme in the de novo purine synthesis pathway (15).

Although one or a combination of these mechanisms may explain the inhibition of de novo purine synthesis by hypoxanthine, the site of production and mechanism of transport of the hypoxanthine found in high concentration in human bone marrow remains unknown. Bertles and Beck (22) noted that reticulocytes release hypoxanthine and other purines during maturation and proposed that these materials might be 


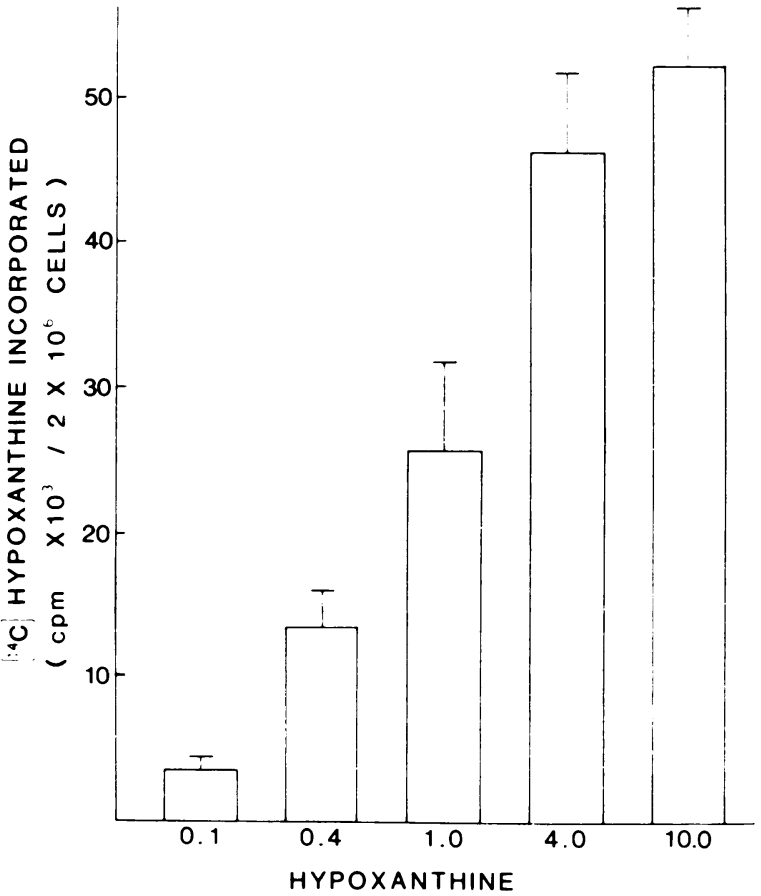

Figure 3 Effect of media hypoxanthine concentration (micromolar) on rates of hypoxanthine salvage. HL-60 cells were incubated for $90 \mathrm{~min}$ in varing media hypoxanthine concentrations containing $\left[{ }^{14} \mathrm{C}\right]$ hypoxanthine at a specific activity of $56 \mathrm{mCi} / \mathrm{mmole}$. $\left[{ }^{14} \mathrm{C}\right] \mathrm{Hy}$ poxanthine incorporation into RNA and DNA was then determined and is displayed as a function of media hypoxanthine concentration.

utilized by neighboring cells. In view of the low rate of de novo purine synthesis in bone marrow tissue (1-4), however, it is likely that extracellular hypoxanthine originates elsewhere. In this regard, Lajtha and Vane (6) demonstrated that $\left[{ }^{14} \mathrm{C}\right]$ formate incorporation

TABLE I

Effect of Media Hypoxanthine Concentration on Rates of RNA and DNA Synthesis

\begin{tabular}{lrccc}
\hline & \multicolumn{5}{c}{ Media hypoxanthine concentration } \\
\cline { 2 - 5 } & \multicolumn{5}{c}{$\mu M$} \\
Nucleoside & \multicolumn{5}{c}{0} & 0.1 & 1.0 & 10.0 \\
\hline$\left[{ }^{3} \mathrm{H}\right]$ Uridine & $91 \pm 18$ & $82 \pm 18$ & $96 \pm 18$ & $100 \pm 10$ \\
{$\left[{ }^{3} \mathrm{H}\right]$ Thymidine } & $104 \pm 14$ & $87 \pm 3$ & $98 \pm 10$ & $100 \pm 14$ \\
\hline
\end{tabular}

HL-60 cells were preincubated in varying concentrations of hypoxanthine for $60 \mathrm{~min}$ and subsequently exposed to either $\left[{ }^{3} \mathrm{H}\right]$ uridine or $\left[{ }^{3} \mathrm{H}\right]$ thymidine for $30 \mathrm{~min}$. Isotopic incorporation into RNA or DNA was then determined. Results are expressed as a percentage of controls (the incorporation found when the media hypoxanthine concentration was $10 \mu \mathrm{M}) \pm 1 \mathrm{SD}$. Control values averaged 3,178 cpm/point for $\left[{ }^{3} \mathrm{H}\right]$ uridine and $267 \mathrm{cpm} /$ point for $\left[{ }^{3} \mathrm{H}\right]$ thymidine. into rabbit bone marrow purines was reduced by hepatectomy, implying that the liver was supplying purines to bone marrow cells. Rabbit liver was also shown to synthesize and release adenosine, which was rapidly taken up by erythrocytes in hepatic sinusoids $(23,24)$. In other studies, erythrocytes were implicated as a vehicle for purine transport from the liver to peripheral tissues (25). The major purine released from rabbit erythrocytes has been identified as hypoxanthine $(26$, 27 ), suggesting that this base may be the purine transferred to peripheral tissues by the erythrocyte. In addition, hypoxanthine has been shown to be rapidly and efficiently cleared from plasma by the liver and hepatic adenosine release has been shown to be proportional to the concentration of hypoxanthine perfusing the liver (24).

These historical observations and the data presented in this report are consistent with the following hypothesis. Adenosine, synthesized in the liver, may be taken up by erythrocytes in hepatic sinusoids, transported to peripheral tissues, and released in the form of hypoxanthine. This hypoxanthine may then be utilized by tissues such as bone marrow and intestine for purine nucleotide synthesis through the salvage pathway. Hypoxanthine not utilized in this manner, as well as that originating from purine catabolism, may eventually be returned to the liver where it is efficiently cleared from the plasma and reutilized or excreted. This hypothesis establishes a mechanism for purine homeostasis. It also explains the low rates of de novo purine synthesis and the high concentrations of hypoxanthine found in bone marrow tissues, and is supported by the results of this investigation suggesting a regulatory role for hypoxanthine in human bone marrow purine metabolism.

The ability of hypoxanthine to regulate purine synthesis also has significance for cancer chemotherapy. In a recent report, hypoxanthine (at concentrations found in the supernatent of human bone marrow or in the plasma of patients with acute leukemia receiving allopurinol) was shown to significantly reduce the cytotoxicity of several purine antimetabolites in vitro using a clonogenic assay technique (7). These results suggest that fluctuations in hypoxanthine concentration may also markedly influence the toxicity of these purine antimetabolites in human bone marrow. Further information is needed on the metabolism of hypoxanthine and the regulation of levels of this purine in plasma and bone marrow.

\section{ACKNOWLEDGMENTS}

The authors would like to thank Sharon Don for assistance in preparing the manuscript. This research was conducted in part by the Clayton Foundation for Research-California Division. 
This work was supported by grants CA 09290 and CA 25336 from the National Cancer Institute.

\section{REFERENCES}

1. Abrams, R., and J. M. Goldfinger. 1951. Utilization of purines for nucleic acid synthesis in bone marrow sites. Arch. Biochem. Biophys. 30:261-268.

2. Abrams, R., and J. M. Goldfinger. 1952. Formation of nucleic acid purines from hypoxanthine and formate in bone marrow slices. Arch. Biochem. Biophys. 35:243247.

3. Trotter, J. R. 1954. Incorporation of isotopic formate into the thymine of bone marrow deoxyribonucleic acid in vitro. J. Am. Chem. Soc. 76:2196.

4. Trotter, J. R., and A. N. Best. 1955. The metabolism of formate- $\mathrm{C}^{14}$ by rabbit bone marrow in vitro. Arch. Biochem. Biophys. 54:318-329.

5. Mackinnon, A. M., and D. J. Deller. 1973. Purine nucleotide biosynthesis in gastrointestinal mucosa. Biochim. Biophys. Acta. 319:1-4.

6. Lajtha, L. G., and J. R. Vane. 1958. Dependence of bone marrow cells on the liver for purine supply. Nature (Lond.). 182:191-192.

7. Wung, W. E., and S. B. Howell. 1981. Hypoxanthine (Hyp) concentrations in human biological fluids and their significance for purine antimetabolite activity. Proc. Am. Assoc. Cancer Res. 22:243.

8. Tattersall, M. H. N., P. Slowiaczek, and A. De Fazio. 1982. Regional variation in extracellular purine levels in vivo. J. Clin. Chem. Clin. Biochem. 20:424-425.

9. Scott, J. L. 1962. Human leukocyte metabolism in vitro. I. Incorporation of adenine-8- $\mathrm{C}^{14}$ and formate- $\mathrm{C}^{14}$ into the nucleic acids of leukemia leukocytes. J. Clin. Invest. 41:67-79.

10. Brockman, R. W., and S. Chumley. 1965. Inhibition of formylglycinamide ribonucleotide synthesis in neoplastic cells by purines and analogs. Biochim. Biophys. Acta. 95:365-379

11. Henderson, J. F., and M. K. Y. Khoo. 1965. On the mechanism of feedback inhibition of purine biosynthesis de novo in Ehrlich ascites tumor cells in vitro. J. Biol. Chem. 240:3104-3109.

12. Hershfield, M. S., and J. E. Seegmiller. 1976. Regulation of de novo purine biosynthesis in human lymphoblasts. J. Biol. Chem. 251:7348-7354.

13. Hershfield, M. S., and J. E. Seegmiller. 1977. Regulation of de novo purine synthesis in human lymphoblasts. $J$ Biol. Chem. 252:6002-6010.

14. Thompson, L. F., R. C. Willis, J. W. Stoop, and J. E.
Seegmiller. 1978. Purine metabolism in cultured human fibroblasts derived from patients deficient in hypoxanthine phosphoribosyltransferase, purine nucleoside phosphorylase, or adenosine deaminase. Proc. Natl. Acad. Sci. USA. 75:3722-3726.

15. Itakura, M., R. L. Sabina, and P. W. Heald. 1981. Basis for the control of purine biosynthesis by purine ribonucleotides. J. Clin. Invest. 67:994-1002

16. Collins, S. J., R. C. Gallo, and R. E. Gallegher. 1977. Continuous growth and differentiation of human myeloid leukemic cells in suspension culture. Nature (Lond.). 270:347-349.

17. Boyum, A. 1968. Isolation of mononuclear cells and granulocytes from human blood. Scand. J. Clin. Lab. Invest. 21(Suppl. 97):77-89.

18. Khym, J. X. 1975. An analytical system for rapid separation to tissue nucleotides at low pressure on conventional anion exchanges. Clin. Chem. 21:1245-1252.

19. Willis, R. C., R. K. Robins, and J. E. Seegmiller. 1980. An in vivo and in vitro evaluation of $1-\beta$-D-ribof uranosyl-1,2,4-triazole-3-carboxamidine: an inhibitor of human lymphoblast purine nucleoside phosphorylase. Mol. Pharmacol. 18:287-295.

20. Murray, A. W. 1971. The biological significance of purine salvage. Annu. Rev. Biochem. 40:773-826.

21. Jackson, R. C., and R. J. Harktader. 1981. The contributions of de novo and salvage pathways of nucleotide biosythesis in normal and malignant cells. In Nucleotides and Cancer Treatment. M. H. N. Tatersall and R. M. Fox, editors. Academic Press Australia, Sydney. I:18-31.

22. Bertles, J. F., and W. S. Beck. 1962. Biochemical aspects of reticulocyte maturation. J. Biol. Chem. 237:37703777.

23. Lerner, M. H., and B. A. Lowy. 1974. The formation of adenosine in rabbit liver and its possible role as a direct precursor of erythrocyte adenine nucleotides. J. Biol. Chem. 249:959-966

24. Pritchard, J. B., N. O'Connor, J. M. Oliver, and R. D. Berlin. 1975. Uptake and supply of purine compounds by the liver. Am. J. Physiol. 229:967-972.

25. Henderson, J. F., and G. A. LePage. 1959. Transport of adenine-8- $\mathrm{C}^{14}$ among mouse tissues by blood cells. $J$. Biol. Chem. 234:3219-3223.

26. Mager, J., A. Hershko, R. Zeitlin-Beck, T. Shoshani, and A. Razin. 1967. Turnover of purine nucleotides in rabbit erythrocytes. I. Studies IN VIVO. Biochim. Biophys. Acta. 149:50-58.

27. Hershko, A., A. Razin, T. Shoshani, and J. Mager. 1967. Turnover of purine nucleotides in rabbit erythrocytes. II. Studies IN VITRO. Biochim. Biophys. Acta. 149:5973. 